\title{
An Analysis on Students' Difficulties in Speaking
}

\author{
Baiq Suprapti Handini $^{1)}$, Ari Prasetyaningrum ${ }^{2)}$, Selamet Riadi Jaelani ${ }^{3)}$, Muhammad \\ Faza Fauzan Azima \\ ${ }^{1}$ Universitas Hamzanwadi \\ annsue14@gmail.com \\ ${ }^{2}$ Universitas Hamzanwadi \\ aripras@gmail.com \\ ${ }^{3}$ Universitas Hamzanwadi \\ selametriadijaelani@yahoo.com \\ ${ }^{4}$ Universitas Hamzanwadi \\ fazariders@gmail.com
}

Received: $5^{\text {th }}$ June 2021, Revised: $9^{\text {th }}$ June 2021, Accepted: $26^{\text {st }}$ June 2021

Email Correspondence: annsue14@gmail.com

\begin{abstract}
The purpose of this research is to analyze the students' difficulties in speaking English especially in introducing themselves self at MTS NW Al Hidayah Baremayung. Besides, this study tries to identify what the students' difficulties in speaking English and what the factors of students' difficulties in speaking English especially in introducing themselves. The method of collecting data was observation, recording, and interview. The data were taken from the subject of the research in the form of teaching learning process, interview and recording. The result of this research shows that the students' difficulties in speaking English especially in introducing themselves are: (a) the student's low vocabulary mastery; (b) the students had difficulties in pronouncing certain words; (c) the students were still confused in arranging words; (d) the students were often afraid in speaking English.
\end{abstract}

Keywords: speaking difficulties, introducing themselves

\section{INTRODUCTION}

English is learned seriously by many people to have a good prospect in the community of international world. Recently, English becomes important. Since it is important, English is taught widely at formal schools starting from elementary school up to universities, even at informal school i.e. courses (Naghdipour 2016). The use of English as the second language in oral communication is complex activities to be considered when teaching the English language (Al Nakhalah 2016).

In Learning English, we need to understand the four skills namely: listening, speaking, reading, and writing because these four skills can help us to master English easily. As one of the skills in learning language, speaking enables people to send and receive information or messages to others.

According to (Pérez, Carreiras, and Duñabeitia 2017) "speaking is an interactive process of constructing meaning that involves producing and receiving and processing information". In addition (Ting-Toomey and Dorjee 2018) states that "speaking is a process of building and sharing meaning through the uses of verbal and non-verbal symbol in various contexts". Speaking is one of the four 
skills in English subject as a tool to communicate each other (Binti Mistar and Embi 2016). In short, speaking skill is the ability to perform the linguistic knowledge in the actual communication.

Introduction is a way to connect with other human beings. Before we establish relationships with other humans we must introduce ourselves first so that we can know information about each other's personal data. Introduction is very important to do before we want to make friends with others (Zemach and Rumisek 2016). It has become a tradition that have to be done well when we start going to school, going to college, but in reality there are a lot of EFL students still find difficult to introduce themselves properly and correctly (Kwon 2017). According to (Machado et al. 2017) "expressing yourself is defined as an activity that expresses how you are reacting to a situation that occurred at that moment and provides information about past experiences".

The problem that many students face when introducing themselves is they are shy, lack of ideas, afraid, and lack of vocabulary (Megawati and Mandarani 2016). This research want to find out the difficulties of the students' at speaking skills, factors that cause students' difficulties and their strategies which is used to overcome difficulties in Speaking English.

\section{RESEARCH METHOD}

In this research, the researchers used descriptive qualitative method. According to (Creswell and Poth 2016) "Descriptive qualitative research is a research method that is based on the philosophy of post positivism which is usually used to examine conditions objective nature in which the researchers acts as a key instrument". Descriptive research tends to use analysis. The process and meaning (subject perspective) is more highlighted in qualitative research. The theoretical foundation is used as a guide so that the focus of research is in accordance with the facts in the field.

The population of this study was all the eighth grade students in MTS NW Baremayung. that consist of 18 students as the sample. In this study the present researchers collected the data by using some instruments namely interview, questioner and observation. In process collecting the data the researchers directly asked the participants some questions about self introduction.

According to (Zina 2021), "Research instruments are simply devices for obtaining information relevant to your research project". The instrument used in this research was interview, questionnaire and observation.

In the process of collecting data, the present researchers used interview, questionnaire and observation. Interview is often referred to oral questionnaires, it is a dialogue conducted by the interviewer to obtain information from the person being interviewed, (Powney and Watts 2018). Interview is used by researcherss to assess a person's situation, for example to look for data about student's background variables, parents, education, attention, and behavior. See also (Muhid, Machmoed, and Hakim Yassi 2020)

According to (Rini 2020) that questionnaires are doubtless one of the primary sources of 
obtaining data in any research endeavor. Questionnaires are a number of written questions that are used to obtain information from respondents about something to be studied. Observation is one of the techniques that are used to collect the data. The researchers are able to find the answers by focusing and taking participant in an event or activity. According to (Chambliss and Schutt 2018)observation is taking regular conscious notice classroom action and occurrences, which are particularly relevant to the issues or topics investigating.

The researchers used an observation involving collecting the data, reducing the data, presenting the data and drawing conclusion. After collecting the data, the researchers reduce and present the data. In reducing the data, the researchers reject meaningless data, so the researchers got the important points of finding. It is followed by presenting the data, it means that the researchers presents about the data systematically and logically, so the meaning of every clear event. By the end of collecting the data, the researchers tried to verify the data based on reduction and data presentation.

\section{FINDING AND DISCUSSION}

The research results were gained from two resources namely a questionnaire and interview. The questionnaire results can be shown in Table 1.

Table 1. Data of Questionnaire

\begin{tabular}{llccccc}
\hline No & STATEMENT & SA & A & N & D & SD \\
\hline 1. & I know about speaking & 0 & 5 & 4 & 8 & 1 \\
\hline 2. & I like speaking & 0 & 3 & 5 & 7 & 3 \\
\hline 3. & I found difficulty when I speaking & 7 & 8 & 2 & 1 & 0 \\
\hline 4. & I have problem in pronunciation when speak & 4 & 7 & 5 & 2 & 0 \\
\hline 5. & $\begin{array}{l}\text { I have to learn how to produce a word correct } \\
\text { to developed my speaking skill }\end{array}$ & 9 & 5 & 3 & 1 & 0 \\
\hline 6. & I know how to introducing my self & 2 & 5 & 4 & 6 & 1 \\
\hline 7 & $\begin{array}{l}\text { I feel nervous when introducing my self in } \\
\text { front of the class }\end{array}$ & 8 & 5 & 3 & 2 & 0 \\
\hline
\end{tabular}

Notes :SA (strongly Agree, A (Agree), N (Neutral), D (Disagree), SD (strongly Disagree)

Based on the interview conducted by the present researchers in MTS, NW Al Hidayah Baremauyung, it showed most students' did not know how to introduce them; they still found some obstacles in introducing themselves. The researchers found that students' very difficult to pronounce words fluently and they have very little vocabulary. The level of students' in introducing themselves can be said very weak based on the results of the interviews and questions. Based on table above, it can be interpreted that there are some factors that influence the students' difficulties in speaking especially in introducing themselves, those are lack of vocabulary, unable to produce words correctly, the student are not confident in introducing themselves, and lack of practice of students' in speaking English. Furthermore, from all questions, there was one question that all students' answer 
negatively that is about what kind of tenses that should be use when introducing themselves. It is mean that the students' difficulty to introduce themselves influenced by tenses.

Based on the results of the essay questions, shows the weakness of students in introducing themselves even though essay questions are very essay, for example:
a. My complete name is...
b. My call name is...
c. I am from...
d. I am... years old
e. My hobby is...

Many students found it difficult when asked to answer the questions above, write names, hobbies, address. Many of them do not know the meaning of the essay questions, even though the sentences often heard since elementary school. From the table below, we can draw conclusions that the students' really need more attention from the teacher especially English teacher because seen from the ability of students' and their interest in English very less. Even one of students' said "English is a hypocritical language, different written other way of saying it, so why should learn English" from that statement it was very clear his disinterest in learning English. The reason had become a culture among students' they considered learning English very difficult.

\begin{tabular}{clcc}
\hline \multicolumn{1}{c}{ Table 2. Data of Interview } & & \\
\hline No & \multicolumn{1}{c}{ STATEMENT } & YES & NO \\
\hline 1 & Do you able to speak English? & 2 & 16 \\
\hline 2 & Do you know part of introducing self? & 5 & 13 \\
\hline 3. & Do you able to produce a word correctly? & 1 & 17 \\
\hline 4 & Are you shy to introducing yourself? & 15 & 3 \\
\hline 5 & $\begin{array}{l}\text { Do you know the words that should be mentioned in introducing } \\
\text { yourself? }\end{array}$ & 4 & 14 \\
\hline 6 & Are you difficult in vocabulary when you introducing yourself? & 15 & 3 \\
\hline 7 & Do you know tenses that use in introducing yourself? & 0 & 18 \\
\hline 8 & Do you often to introduce yourself? & 4 & 14 \\
\hline
\end{tabular}

From the result of the interview and questionnaire, it was found that there are some main problems in speaking especially in introducing themselves. The first is lack of vocabulary. When the students were speaking to introduce themselves they are often speechless because they had a lot of vocabulary in condition was caused by lack of emphasis on memorizing vocabulary by the teacher. The second factor is difficulty in producing words correctly. In this case, the present researchers found that most of students' wrongly in mention words. Most of the students' does not want to speak because they do not know how to produce the words. This condition was caused by the students seldom learn how to spell the words. The third is the students' confidence. When the researchers 
asked the students to introduce themselves in front of their friends, most of them feel shy and afraid. This condition occurred because students are not accustomed to speak English and rarely practice.

Based on the explanation above, the present researchers claim that there are three main problem that face by students' in speaking especially in introducing themselves. According to (Baker and Burri 2016)"the problem which is often faced by the students is about pronunciation. They felt difficult to pronounce certain words because in English, between pronunciation and writing are different. Therefore, they did not recognize yet". From all the difficulties, students had the most difficulty in pronouncing words correctly and did not have a large of vocabulary. In addition, based on relevant study that was conducted by Sari (2017) entitled students' difficulties in speaking skill at the eleventh grade of SMA Muhammadiyah 1 Karanganyar. It was found that every student had different difficulties in speaking. They are inhibition, nothing to say, event participant, and mother tongue. Based on the result of previous research above, the present researchers concluded that the students' difficulty in speaking especially in introducing themselves was caused by inhibition, nothing to say, un-event participant, and mother tongue.

\section{CONCLUSION}

Based on this research finding the present researchers concluded that the students' difficulty of MTS NW Al Hidayah Baremayung in speaking especially in introducing themselves are, students' of MTS NW Baremayung has lack of vocabulary, they cannot produce words correctly, and they are not confident when introduce themselves. The level of students' in introducing themselves is very weak, because the students' seldom learn how to spell the words. This condition occurred because students are not accustomed to speak English and rarely practice and lack of emphasis on memorizing vocabulary by the teacher.

\section{REFERENCES}

Baker, Amanda Ann, and Michael Burri. 2016. "Feedback on Second Language Pronunciation: A Case Study of EAP Teachers' Beliefs and Practices."

Binti Mistar, Izyani, and Mohamed Amin Embi. 2016. "Students 'perception on the Use of WhatsApp as a Learning Tool in ESL Classroom." Journal of Education and Social Sciences 4: 96-104.

Chambliss, Daniel F, and Russell K Schutt. 2018. Making Sense of the Social World: Methods of Investigation. Sage Publications.

Creswell, John W, and Cheryl N Poth. 2016. Qualitative Inquiry and Research Design: Choosing among Five Approaches. Sage publications.

Kwon, Yunghwan. 2017. "A Study of Thai Teachers' Perceptions toward the Implementation of Communicative Language Teaching of English.” HRD Journal 8(1): 114-25.

Machado, Alencar et al. 2017. "Reactive, Proactive, and Extensible Situation-Awareness in Ambient Assisted Living." Expert Systems with Applications 76: 21-35.

Megawati, Fika, and Vidya Mandarani. 2016. "Speaking Problems in English Communication."

Muhid, Abdul, Hamzah.A. Machmoed, and Abdul Hakim Yassi. 2020. Convergence as Communication Strategy. 1st ed. ed. Syamsurrijal. Makassar: Yayasan Barcode. 
Naghdipour, Bakhtiar. 2016. "English Writing Instruction in Iran: Implications for Second Language Writing Curriculum and Pedagogy." Journal of Second Language Writing 32: 81-87.

Al Nakhalah, Ahmed Maher Mahmoud. 2016. "Problems and Difficulties of Speaking That Encounter English Language Students at Al Quds Open University." International Journal of Humanities and Social Science Invention 5(12): 96-101.

Pérez, Alejandro, Manuel Carreiras, and Jon Andoni Duñabeitia. 2017. "Brain-to-Brain Entrainment: EEG Interbrain Synchronization While Speaking and Listening." Scientific reports 7(1): 1-12.

Powney, Janet, and Mike Watts. 2018. Interviewing in Educational Research. Routledge.

Rini, Mustika. 2020. "Students' and Teachers' Beliefs on English Language Teaching: A Study in One Islamic Boarding School." Edukasi: Jurnal Pendidikan dan Pengajaran: 47-56.

Saputra, Ari, Sutarman, and Syamsurrijal. 2020. "Designing Life Skill - Based English Reading Materials For Second Grade Students Of SMA Negeri 1 Pringgasela." Humanitatis :Journal of Language and Literature 6(2): 297-322. https://journal.universitasbumigora.ac.id/index.php/humanitatis/article/view/793/52.

Ting-Toomey, Stella, and Tenzin Dorjee. 2018. Communicating across Cultures. Guilford Publications.

Zemach, Dorothy E, and Lisa Rumisek. 2016. Academic Writing. Macmillan.

Zina, O. 2021. The Essential Guide to Doing Your Research Project. Sage. 